\title{
In the Name of the Mother \\ Sexual Difference and the Practice of 'Entrustment'
}

\section{SUSANNA SCARPARO}

MONASH UNIVERSITY

\begin{abstract}
If I position myself within the mother's genealogy, if I measure myself in terms of a relationship with another woman, if I place maternal authority above established power-if I create a new symbolic-then it is another world, in the more practical and realistic sense. This is what many already practice.
\end{abstract}

Luisa Muraro ${ }^{1}$

Discussing three recent Italian films which aim to recount the past thirty-five years of the nation's political history, the journalist Ida Dominijanni points out that mainstream narratives fail to take into account the role of the 'feminist revolution' in Italy. These narratives claim that 1970s feminism was a great social revolution but it failed to make a breach in the world of politics which is still entirely a male bastion, impenetrable then and now to women, as is evidenced by the insignificant percentages of women in parliament and in top party or government jobs. ${ }^{2}$

Those making this claim assess the effects of what can be called a 'feminist revolution' on politics by measuring such effects on the very same scale of power and employing the same definition of 
politics that feminism has challenged so dramatically. They fail to understand the extent to which the Italian feminism of sexual difference has been and continues to be not only a social, but an intrinsically political movement.

In the Anglophone west, mainstream narratives usually take for granted that, by and large, feminism and the women's movement have been almost successful in achieving one of their principal aims, namely equality with men. There, the popular debate about relations between the sexes focuses predominantly on three key concepts: rights, equality and emancipation for women. ${ }^{3}$ In Anglo-American countries feminism has often been portrayed as a political movement which had a great influence in changing legislation and social relations but which (for these very reasons) has also run its course. For my Australian students, feminism has become synonymous with feminist theories, to be studied at university but seldom needed in their private lives.

In the past twenty-five years, many Italian philosophers, teachers and academics have developed understandings of their roles as feminist intellectuals that differ markedly from those held by feminists influenced by the Anglo-American paradigm. The latter have tended to be more concerned with practical work geared towards emancipatory legislation and the achievement of equal rights for women, whereas many Italian feminists have been interested in theorising a politics of sexual difference based on the recognition of a difference between men and women. Such difference, as the Milan Women's Bookshop Collective notes, 'is not one culturally constructed from biology and imposed as gender', but rather 'a difference in symbolization, a different production of reference and meaning out of a particular embodied knowledge'. ${ }^{4}$

In this article, I discuss how by establishing a relationship between theories and practices, the Italian feminism of sexual difference poses both a radical challenge to feminism as the struggle for equality with men, and to the notion of politics understood as the struggle for power. Sexual difference theorists define politics in terms of relationships between human beings. Focusing on the practice of affidamento (entrustment), I show how the political 'mode' of the feminism of sexual difference is not primarily founded on the 'identification and vindication of women's rights' but rather on the 'activation of female subjectivity in order to produce sociosymbolic change'. 5 The Italian feminism of sexual difference does not stress women's right to enter politics, but instead questions the character of traditional politics itself and in so doing seeks to create a new symbolic order. Its criticism of traditional politics is radical: it 'cuts across the crisis of politics, thereby showing an alternative that did not mean adding women to an existing scenario but rather, creating a new scenario'. 6

The Italian feminism of sexual difference should be of great interest to those interested in socio-symbolic change. It may be of particular interest to women who, like me, feel that 
feminism in countries such as Australia has reached an impasse. Arguably, the growing number of women involved in institutional politics, or holding managerial positions in private firms or at universities, has been able neither to change those institutions nor to create a new scenario. This is confirmed by the precariousness of many of the gains that many may have taken for granted: the right to terminate a pregnancy, the ability to access affordable childcare, the right not to be killed by one's husband, and so on. The fact that a jury in Melbourne recently convicted a man who killed his wife of manslaughter not of murder, on account of having his being provoked by her, shows that feminism in Australia has succeeded in sending more women to parliament and in acquiring more institutional power for women, but has failed to create a new symbolic order. ${ }^{7}$ At the risk of sounding utopian, I wish to argue for ways in which such a change may be imagined, if not attempted.

In Italy, the production and practice of feminist thought has operated mostly outside the academy. With the exception of a few interdisciplinary centres, and a handful of postdoctoral programs, there are no women's studies degree courses in Italy. There are, however, feminist journals and magazines, and several active and autonomous women's cultural centres and bookshops. ${ }^{8}$ The latter includes the Women's Bookshop Collective in Milan, introduced to Anglophone readers by Teresa de Lauretis through her translation of their seminal book Non credere di avere dei diritti. ${ }^{9}$ Another key voice is that of the well-established philosophical community Diotima in Verona. Founded in 1984, Diotima consists of a core of ten members who are linked to intellectuals based in other parts of Italy. They publish books under the collective name Diotima. Their project is to appropriate 'a philosophical voice in the knowledge, rather than exclusion or transcendence, of sexual difference'.10 Many of the centres and associations scattered throughout the peninsula take the sexual difference theory as a starting point and as a way to analyse issues specific to them. To name a few examples: the Associazione Lucrezia Marinelli focuses on women's cinema, La città felice di Catania on the city of Catania, and other groups, such as Donne in nero di Ravenna, oppose the Italian participation in recent wars and form part of an international network of anti-war feminist activists. There are also strong links between the Milan Women's Bookshop Collective and similar associations in Spain and Germany. ${ }^{11}$

Among the younger generation (mainly women in their twenties and thirties), there is a developed network of small groups of women and some men who meet regularly to discuss issues such as the notion of a 'just' war and workplace relations, as well as issues relating to the politics of power and the intergenerational relationships between feminists. One such group based in Milan, for instance, meets every two weeks and includes women from the Milan bookshop but also from other groups such as sconvegno or Arci lesbian. 
As early as 1970, in her seminal book Let's Spit on Hegel, Carla Lonzi argued in favour of a theory of sexual difference:

equality is a juridical principle ... Difference is an existential principle which concerns the modes of being human, the peculiarity of one's own experiences, goals, possibilities, and one's own sense of existence in a given situation and in the situations one wants to create for oneself. The difference between woman and man is the basic difference of humankind ... Equality is what is offered as legal rights to colonized people. And what is imposed on them as culture. ${ }^{12}$

Lonzi's critical view of equality was further developed by a group of women called Group Number 4 (who were part of the Milan Women's Bookshop Collective). In 1983, this group published the influential essay 'Più donne che uomini' (More Women than Men), which has become known as the green Sottosopra. Its authors lament the fact that they 'have no way of translating the experience, the knowledge and the value of being women into social reality'.13 Hence they argue that the struggle against discrimination should be secondary because the real problem for women lies in the fact that the specificity of being a woman remains excluded from social discourse, 'like an irrelevant particular, which is significant only if the woman takes on the roles bound up with her anatomy'. Her difference is fundamental to her being, yet 'a social role based on anatomy is not freedom, just as there is servitude in a social freedom paid for by the erasure of one's sexed body', which is what equality entails. ${ }^{14}$

According to Luisa Muraro- one of the most prominent proponents of the sexual difference theory today, a founding member of Diotima and a prominent theorist of the Milan Women's Bookshop—sexual equality is not a feminist goal because it encourages women to emulate models they should rather challenge or try to change. Hence, Muraro asks:

is it really necessary for us to accept the paradigm of equality or can we incorporate, in our discussion and in political reality, relations of difference and asymmetry that characterize life, without also opening the door to domination and hierarchy? In other words, can we go beyond the politics of rights? ${ }^{15}$

This is, I believe, an important question if one takes feminism, of whatever kind, to be about 'dismantling the master's house' as opposed to asking that there be a bed for a woman in that house. ${ }^{16}$

For the authors of 'Più donne che uomini', equality means that in social relationships their 'unease has remained completely unspoken'. This is because in social relations, 'the fact of being a woman has proved meaningless, an embarrassing peculiarity' which they had to justify or which they forgot and wanted others to forget.17 Already in 1983 the authors of the essay 
claimed that it is 'no longer a matter of discrimination', but the radical nature of this statement and its implications have been largely ignored by the many critics and commentators who still show their disappointment about what they perceive to be a failure of the Italian feminists to send women to parliament.18 Their understanding of feminism does not take into account the fact that, due to feeling estranged and not at ease in such places, Italian women may not necessarily all want to become parliamentarians. The fundamental problem with this reductive understanding of feminism as driven predominantly by the search for emancipation and homologation to male desire is that it fails to conceive of other ways to define and re-elaborate the notion of politics. Moreover, it does not allow for dismantling the duality whereby women's politics is merely another politics next to the supposedly genderless norm. Hence, as Muraro observes, this view of politics does not allow one to 'place women's politics at the centre of politics'.19

The consequences of this perception are serious. According to Muraro, most people involved in institutional politics think about sexual difference in terms of sharing, aiming to create more spaces for women in society (in parliament, political parties, churches, universities, the media and so on), and believing that this is a practice of sexual difference. In reality this is a politics of integration of women in a male world that runs the risk of 'ending up in the selfconfinement of the female subject'.20

How then may it be possible to think differently-and in ways that do not lead to the selfconfinement of the female subject-about politics in terms of sexual difference? For Italian feminists who promote a theory of sexual difference, sexual difference is neither only biological 'sex', nor only culturally created 'gender'; rather it is the inscription of both of these in the symbolic domain. The aim is to create a discourse of signification and modification not only of the social but also of the symbolic order. For these feminists, the theoretical work necessary to achieve such an aim must not come merely from the desire to belong to parliament or other institutions, but must come from a sustained reflection of what they call la pratica (the practice). This means that the theory they produce aims to be a practical philosophy, since it is a theory entirely centred on a pratica del fare (practice of doing). This 'doing', however, is not centred on legal and social action as in, for instance, the opening of women's shelters, or campaigning for women's rights and so on. Rather, it is a philosophical doing entirely based on two modi operandi: the so-called pratica del partire da sé (practice of beginning from oneself) and the pratica delle relazioni (practice of relations).

According to one of the philosophers of Diotima, Chiara Zamboni, the pratica del partire da sé was a direct legacy of the women's liberation movement. Zamboni describes this practice as a necessity to reconstruct one's past and to understand the feelings and contradictions we deal with ordinarily: 'This is what we talk about: a politics that is able to treasure and turn into 
treasure our lived experience and our desires'. ${ }^{21}$ This practice leads to 'a practical philosophy'. According to Muraro, a practical philosophy is a philosophy of those who think through a modification of themselves. ${ }^{22}$ It is a self-determined process of critical understanding and sociocultural change that subverts the categories of Western thought whereby women come to occupy the position of speaking subjects as-rather than in spite of their being-females. ${ }^{23}$

The philosophical doing at the heart of the sexual difference theory requires a shift from the notion of emancipation to that of freedom. The free understanding of oneself and the world around oneself must necessarily be reconfigured and rethought beginning from one's own gendered experience (as somebody who is either a man or a woman). This practice, called la pratica del partire da sé, beginning from oneself, implies taking oneself as a starting point.

This is to be distinguished from what has become known as 'standpoint theory', which is rooted in Marxist theory and seeks to analyse the notion of a standpoint as an epistemological device in order to 'discover a feminist standpoint on which to ground a specifically feminist historical materialism'. ${ }^{24}$ In the words of Nancy Hartsock, 'as Marx's understanding of the world from the standpoint of the proletariat enabled him to go beneath bourgeois ideology', so a feminist standpoint can allow women 'to understand patriarchal institutions and ideologies as perverse inversions of more humane social relations'. ${ }^{25}$ For the theorists of sexual difference, the aim is not the Marxist moment of collective liberation that would bring forth 'more humane social relations', but the attainment of individual freedom. The difference between liberation and freedom is a difference between a project in the future and the acting in the present. ${ }^{26} \mathrm{By}$ 'individual' I do not mean the modern 'individual' as configured by liberal Western thought. Rather, I wish to evoke the notion of a singularity-in-between, which indeed questions the very notions of the universal subject.

As Dominijanni describes it, this type of freedom is ' a freedom in deed and practice, an event which is manifested and renewed each time it modifies the social and symbolic order, shifting power relations or opening up spaces of meaning and significance'. ${ }^{27}$ Hence, it is not a collective but rather an individual shift in understanding. Indeed, it is a freedom that does not demand vindication of the rights of women or equality under the law, and that is obtained through the modification of oneself and one's understanding of the world. ${ }^{28}$

Yet this modification of oneself and one's understanding of the world cannot happen in isolation (hence the different meaning of 'individual'). In the 1970s, Italian women attempted to modify the symbolic order through la pratica dell'autocoscienza (the practice of consciousnessraising). Autocoscienza is a term coined by Carla Lonzi to describe the practice of small groups of women who met to talk about themselves or anything else that was based on their personal experience. This practice was adapted from North American feminism, but unlike the English expression 'consciousness-raising', the term autocoscienza (self-consciousness or consciousness 
of self) emphasised the self-determined and self-directed element fundamental to achieving the new consciousness/awareness. Furthermore, as Lucia Re explains:

this process of self-discovery was also the process of establishing a collective sense of self with other women, and an expression of the need for a common language and a philosophical framework through which to reflect on the implications of sexual difference.

Teresa de Lauretis also points out that the impact of this first practice was 'perhaps stronger and ultimately more significant for the development of feminist theory in Italy than in North America'. ${ }^{29}$ Wishing to take their new insight and theoretical gains outside their consciousnessraising groups and into a wider context of social relations, many feminists who practiced autocoscienza moved from that theoretical practice to la pratica delle relazioni. Muraro claims that this practice frees the women involved from the paradigm of equality and the politics of rights because it attempts to go beyond them.

This pratica delle relazioni was formally theorised in the second part of the essay 'Più donne che uomini', which I mentioned previously. Here it is called la pratica dell'affidamento. The word affidamento (literally 'entrustment') has since been abandoned because it was perceived to be too narrow in focus, but the practice is still fundamental to the theoretical reflection of all women and men involved in the sexual difference networks, groups, communities and associations. This practice has been defined as 'the recognition of, and reliance on, differences in competence between women'.30 In simple terms, a woman recognises that another woman has something more, un di più (as it is generally called), which, she believes, will also help her realise her full potential and mediate her access to the social world. This recognition fuels her desire to enter into a relationship of 'entrustment' with the other woman. It is important to make two clarifications: first, that entrustment is not an equal relationship between the two women, and second, that the competence of the woman to whom one entrusts oneself does not relate to institutional power. Rather, as Chomsky first defined the word, this particular competence is like the competence of a native speaker of a language who has a specific knowledge (or competence) of that language which is different and goes beyond that of the scholar. It is a knowledge that is intrinsic to the native speaker, that remains in the realm of the symbolic and that will never be comparable to the scientific knowledge of the scholar. ${ }^{31}$

The so-called di più (something more) of the woman who is perceived to have 'competence' is not a di più dependent on the logics of power or ownership but is entirely something to do with one's being. What is significant is also that this difference in competence becomes visible and sometimes is even created through the relationship between the women involved. As Muraro explains, 'dall'essere in relazione con lei ti viene un di più di esistenza' (by being in a relationship with her you acquire something more-un di più-of existence, life). ${ }^{32}$ 
Vital to this practice is the desire to enter into the relationship. This desire is shared by both women but is, by necessity, felt more intensely by the woman who wishes to entrust herself to the other. Muraro defines this desire as 'the desire to enter into a relationship which is the desire for something more than the relationship itself allows you to see'.33 Finally, according to Muraro:

Being in relation with her makes your life richer, more significant. This is because the relation can reawaken and inspire inside the person who wants it and desires it the capacity for modes of existence that the routine of daily life had dulled. So you recognise in the other this skill, this knowing how to be something that you feel inside, this potential that one gains from the relation and with the relation. ${ }^{34}$

Central to affidamento (as the word demonstrates) is the notion of fiducia (trust). However, the word seemingly implies an almost 'blind trust', a 'trusting abandonment to the other', as Muraro calls it, that does not effectively reflect the actual relationship developing between the two parties: a relationship made of conflict as well as harmony. ${ }^{35}$ For this reason the practice of affidamento is now more commonly called la pratica delle relazioni.

The intrinsic anti-egalitarianist attitude of this practice has been criticised in Italy and abroad by left-wing journalists, activists and academics, and much debate has arisen regarding the potentially hierarchical dynamic of affidamento. ${ }^{36}$ Prominent Italian journalists Rossana Rossanda and Miriam Maffai, for instance, criticise the practice for its dyadic relationship pattern, its elitism and its unsuitability for dealing with the masses and with economic and institutional issues. ${ }^{37}$ Others argue that although the practice of 'entrustment' claims to 'empower the mother, it is done at the expense of stifling the daughter'. ${ }^{38}$ Moreover, critics see the 'figure of the older mentor woman' as replacing the 'omnipotent Goddess that feminists deconstructed' and as reiterating 'the standard good mother (me) versus bad mother (them) categories'. ${ }^{39}$ Among academics based in North American universities, critics include established Italianists such as Lucia Re. She conflates the practice of affidamento with the works and modus operandi of Diotima, which she sees as being oriented towards a hierarchical vision of community, modelled on the experience of religious communities. ${ }^{40}$

In my view these interpretations of the practice are based to some extent on a misunderstanding of the radical re-signification of the notion of authority (in particular maternal authority) as something that is radically different from power, and that ideally stems from this practice. This understanding of authority has been central to Diotima's philosophers, who, in fact, are responsible for its re-elaboration and re-signification. As one of Diotima's philosophers argues, 'we have lost access to the original use of the word auctoritas, which comes from the Latin verb augere, meaning the ability to make others grow and prosper, to nurture 
and, almost literally, to augment'. An auctor, therefore, was someone who had the ability to advise and counsel others who needed the auctor to augment their will and their capacity to make decisions and take action. ${ }^{41}$ This is, of course, very different from our common understanding of power, which is connected to the Latin word potestas, meaning force and right. According to Annarosa Buttarelli, in this conceptualisation of power as potestas there is no room for consensus. Rather, power relies predominantly on the exercise of force that is the essential characteristic of domination. The words auctoritas and potestas are linked to the verbs agere (authority) and gerere (power). Whereas agere means to guide, discuss and conduct, gerere means to administer, govern, and have the faculty to act despite opposition from others. ${ }^{42}$

Elsewhere I have discussed in greater depth Diotima's re-signification of the notion of authority, and the important symbolic relationships that inspire the community, such as the female religious communities created by the Beguines. ${ }^{43}$ Here I wish to reiterate the fundamental distinction between authority and power, which has been theorised by Diotima, but which has its origins in the practice of relations. Freeing authority from the framework of paternal authority and placing it in the context of the mother-daughter relationship, Diotima suggest that a freer understanding of authority could result from a focus on the authority of the mother and the maternal language in symbolic terms. This focus on maternal authority also serves to restore a public function to the mother beyond that of being a carer, which 'maternal' traditionally signifies: the 'mother gives life and nourishment but also language to the world' ${ }^{44}$ The woman to whom another woman entrusts herself serves a similar role, and this is why she is also sometimes referred to as the symbolic mother. The di più which is recognised, created and validated by the practice of entrustment, and which helps one to live and strengthens one's life, is what we may call maternal authority.

Discussing female sexuality, Julia Kristeva writes about the daughter's complex process of 'disidentification' from the mother, which leads to the subject becoming the sexual object of a man (that is, the father), but also to an identification with the father as a symbolic figure 'that allows the subject to speak, to think, and to take part in society'. Hence women 'take part in the symbolic order, but only as outsiders'. ${ }^{45}$ For the authors of 'Più donne che uomini', one way to struggle against this predicament and indeed to create a new symbolic order is to give real strength within our relationships to that ancient relationship': the relationship with the mother, which has no form in patriarchal society. Since 'every woman had, in her mother, her first love and her first model', attempting to reproduce such a relationship within the practice of entrustment re-creates maternal authority in symbolic terms. ${ }^{46}$ The recognition of disparity is crucial. Indeed:

To the extent that we can engage in the recognition of disparity, we will be able to find an order, a dynamic, the fertility, of the primary emotions 
linked to the ancient relationship with the mother. With the recognition of the 'something extra' that another woman can be, these old emotions will find a means of positive expression-freeing themselves from ambiguities and us from recriminations. ${ }^{47}$

The symbolic daughter recognises what is valuable in her symbolic mother and sees that value as an element of strength in order to arrive at her own sense of value. The attribution and acquisition of value creates relational authority. By this I mean that this type of authority does not belong to one person as such, but exists within the relationship between two people. It is also reversible, dynamic and linked to specific contexts and moments in time. For instance, it may be the case that at times the symbolic daughter has authority in relation to a specific competence her symbolic mother recognises in her. The moment in which authority ceases to be relational and becomes fixed and owned by one individual, it coincides with power. It is necessary to clarify that this notion of authority is similar to that of power, particularly institutional power, in that they are both vertical. However, the authority that the practice of relations creates distinguishes itself from power in that it does not depend on social hierarchy and institutional mediation. Rather it is based on freedom and desire. It may operate within social institutions, and it may help women negotiate such institutions, but it is not formed by and does not conform to institutional rules.

Much of the contemporary discussion on authority has been shaped by social contract theory, which views individuals as abstract entities irrespective of their sex, class or race. Theorists of authority usually identify leadership with authority, attributing to it recognisable marks such as 'expert knowledge', or the 'occupation of certain offices or roles' or even physiognomy, voice and physical stature, as criteria for recognising authority. ${ }^{48}$

Until the mid 1990s, the concept of authority had either not received extensive treatment in feminist circles or had been conceived as inconsistent with feminist politics. As Kathleen Jones writes:

our efforts have been directed more at investigating how to remove the remaining obstacles to women's being in authority, or how to integrate women into politics, than inquiring about whether women's entering the field of authority as gendered subjects would challenge the terms of authority itself. ${ }^{49}$

What is radical about the sexual difference theorists is precisely the fact that they do not merely 'challenge the terms of authority itself', but rather give the concept an entirely new meaning while validating the word of the mother. This also shifts the discussion on authority from the hallmark of contract to that of relationship, whereby difference between individuals and not equality is constitutive of that which creates authority. The relational nature of authority, 
distinguished from social status and power, is crucial for an understanding of politics intended not as the struggle for power but as that which renders relationships between human beings possible. In this sense authority produces civilisation and, through the practice of relations, politics becomes mediation. As Ida Dominijanni has written,

In this kind of politics, the relationship among/between women is not a matter of organisation, a way to bring women together. It is a site, the 'setting', where female subjectivity can come into being, taking shape from its dis-symmetries with regard to the dominant symbolic order; where it can produce its own representations and evaluations of itself and the world, thereby also modifying its relationship with reality, and reality itself. 50

The implications of this understanding of politics are twofold. First, it helps us to see the limitations of mainstream understandings that wish to reduce feminism to a simple demand for more institutional power for women. Second, by placing maternal authority beyond established power and within the mother's genealogy, this notion of politics seeks to create a new symbolic order in the name of the mother. In practical terms, this means that by forging relationships of entrustment with other women based on maternal authority rather than power, women will be able not merely to 'survive' within institutions and social relations, but will also be able to find strength, validation and self-affirmation, which would encourage them to take the risk of challenging established norms. This practice of entrustment, in turn, brings sexual difference into social relations and creates the conditions for the activation of female subjectivity, and thus has the potential to create socio-symbolic change.

I am indebted to Luisa Muraro, Lia Cigarini, Chiara Zamboni, Ida Dominijanni, Sara Gandini, Elisabetta Marano and Clara Jourdan who were generous with their time and willing to share their knowledge and experience with me in July 2004. An earlier version of this article was presented to the 'Italian Effect' conference in Sydney in September 2004. I wish to thank participants to this conference for their comments. I am also grateful to Klaus Neumann and Bernadette Luciano who read and commented on earlier versions of this article.

Susanna Scarparo is Cassamarca lecturer in Italian Studies at Monash University. She is the author of Elusive Subjects (Troubador, 2005), co-editor of Across Genres, Generations and Borders (University of Delaware Press, 2004), and has written articles on life writing, historical fiction, and Italian Australian literature. <susanna.scarparo@arts.monash.edu.au> 


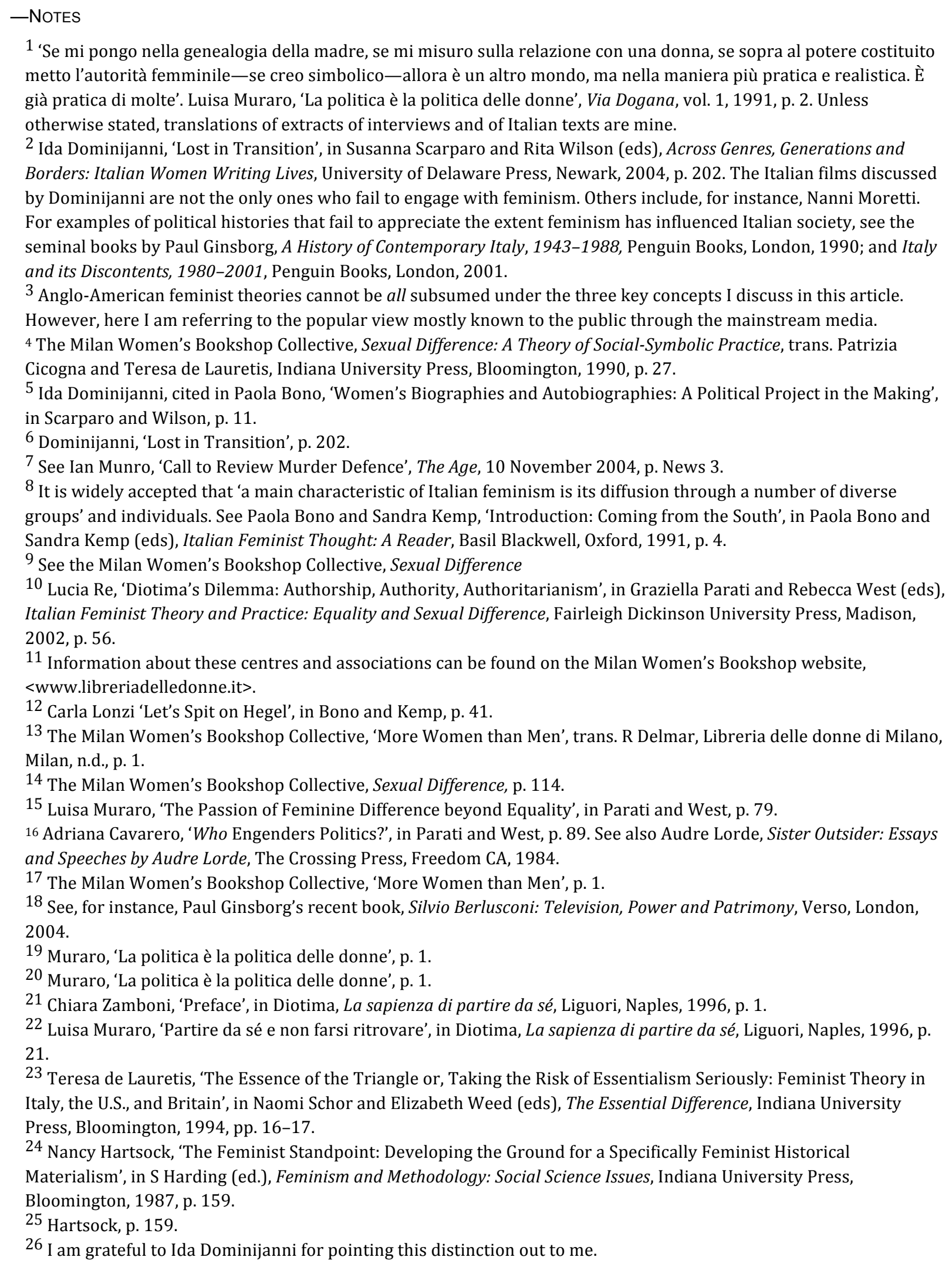

1 'Se mi pongo nella genealogia della madre, se mi misuro sulla relazione con una donna, se sopra al potere costituito metto l'autorità femminile-se creo simbolico-allora è un altro mondo, ma nella maniera più pratica e realistica. È già pratica di molte'. Luisa Muraro, 'La politica è la politica delle donne', Via Dogana, vol. 1, 1991, p. 2. Unless otherwise stated, translations of extracts of interviews and of Italian texts are mine.

2 Ida Dominijanni, 'Lost in Transition', in Susanna Scarparo and Rita Wilson (eds), Across Genres, Generations and Borders: Italian Women Writing Lives, University of Delaware Press, Newark, 2004, p. 202. The Italian films discussed by Dominijanni are not the only ones who fail to engage with feminism. Others include, for instance, Nanni Moretti. For examples of political histories that fail to appreciate the extent feminism has influenced Italian society, see the seminal books by Paul Ginsborg, A History of Contemporary Italy, 1943-1988, Penguin Books, London, 1990; and Italy and its Discontents, 1980-2001, Penguin Books, London, 2001.

${ }^{3}$ Anglo-American feminist theories cannot be all subsumed under the three key concepts I discuss in this article. However, here I am referring to the popular view mostly known to the public through the mainstream media. 4 The Milan Women's Bookshop Collective, Sexual Difference: A Theory of Social-Symbolic Practice, trans. Patrizia Cicogna and Teresa de Lauretis, Indiana University Press, Bloomington, 1990, p. 27.

5 Ida Dominijanni, cited in Paola Bono, 'Women's Biographies and Autobiographies: A Political Project in the Making', in Scarparo and Wilson, p. 11.

${ }^{6}$ Dominijanni, 'Lost in Transition', p. 202.

${ }^{7}$ See Ian Munro, 'Call to Review Murder Defence', The Age, 10 November 2004, p. News 3.

${ }^{8}$ It is widely accepted that 'a main characteristic of Italian feminism is its diffusion through a number of diverse groups' and individuals. See Paola Bono and Sandra Kemp, 'Introduction: Coming from the South', in Paola Bono and Sandra Kemp (eds), Italian Feminist Thought: A Reader, Basil Blackwell, Oxford, 1991, p. 4.

${ }^{9}$ See the Milan Women's Bookshop Collective, Sexual Difference

10 Lucia Re, 'Diotima's Dilemma: Authorship, Authority, Authoritarianism', in Graziella Parati and Rebecca West (eds), Italian Feminist Theory and Practice: Equality and Sexual Difference, Fairleigh Dickinson University Press, Madison, 2002, p. 56.

11 Information about these centres and associations can be found on the Milan Women's Bookshop website, $<$ www.libreriadelledonne.it>.

12 Carla Lonzi 'Let's Spit on Hegel', in Bono and Kemp, p. 41.

13 The Milan Women's Bookshop Collective, 'More Women than Men', trans. R Delmar, Libreria delle donne di Milano, Milan, n.d., p. 1.

14 The Milan Women's Bookshop Collective, Sexual Difference, p. 114.

15 Luisa Muraro, 'The Passion of Feminine Difference beyond Equality', in Parati and West, p. 79.

${ }^{16}$ Adriana Cavarero, 'Who Engenders Politics?', in Parati and West, p. 89. See also Audre Lorde, Sister Outsider: Essays and Speeches by Audre Lorde, The Crossing Press, Freedom CA, 1984.

17 The Milan Women's Bookshop Collective, 'More Women than Men', p. 1.

18 See, for instance, Paul Ginsborg's recent book, Silvio Berlusconi: Television, Power and Patrimony, Verso, London, 2004.

19 Muraro, 'La politica è la politica delle donne', p. 1.

20 Muraro, 'La politica è la politica delle donne', p. 1.

21 Chiara Zamboni, 'Preface', in Diotima, La sapienza di partire da sé, Liguori, Naples, 1996, p. 1.

22 Luisa Muraro, 'Partire da sé e non farsi ritrovare', in Diotima, La sapienza di partire da sé, Liguori, Naples, 1996, p. 21.

23 Teresa de Lauretis, “The Essence of the Triangle or, Taking the Risk of Essentialism Seriously: Feminist Theory in Italy, the U.S., and Britain', in Naomi Schor and Elizabeth Weed (eds), The Essential Difference, Indiana University Press, Bloomington, 1994, pp. 16-17.

${ }^{24}$ Nancy Hartsock, 'The Feminist Standpoint: Developing the Ground for a Specifically Feminist Historical Materialism', in S Harding (ed.), Feminism and Methodology: Social Science Issues, Indiana University Press, Bloomington, 1987, p. 159.

25 Hartsock, p. 159.

26 I am grateful to Ida Dominijanni for pointing this distinction out to me. 
27 Ida Dominijanni, 'Re-thinking Freedom: The Politics of Sexual Difference in Contemporary Italy', unpublished paper delivered at Monash University, Melbourne, 22 October 2003.

28 Teresa de Lauretis makes the points that a freedom that 'paradoxically, demands no vindications of the rights of woman, no equal rights under the law, but only a full, political and personal accountability to women is as startlingly radical a notion as any that has emerged in Western thought'. See de Lauretis, 'The Essence of the Triangle', p. 26.

${ }^{29}$ See Re, 'Diotima's Dilemmas', p. 58; and de Lauretis, 'The Essence of the Triangle' p. 19.

30 Mirna Cicioni, “Love and Respect, Together”: The Theory and Practice of Affidamento in Italian Feminism', Australian Feminist Studies, vol. 10, 1989, p. 71.

${ }^{31}$ I am grateful to Luisa Muraro for explaining this crucial point to me.

32 Luisa Muraro, audio-taped interview, Milan, 23 July 2004.

33 Muraro, audio-taped interview, Milan, 23 July 2004. 'Il desiderio di relazione è il desiderio di un di più che la relazione ti fa intravedere.'

${ }^{34}$ Muraro, audio-taped interview, Milan, 23 July 2004:

Dall'essere in relazione con lei ti viene un'esistenza piu ricca, più significativa, perchè la relazione dentro chi la vuole, la desidera, risveglia e fa sgorgare di nuovo delle potenzialità di essere che magari il tram tram della vita di tutti i giorni avevano addormentato. Allora si riconosce all'altra una competenza, cioè un sapere essere qualcosa che una sente una possibilità anche per se che guadagna dalla relazione e con la relazione.

35 Muraro, audio-taped interview, Milan, 23 July 2004.

${ }^{36}$ For a discussion in English of affidamento and the debate surrounding it, see de Lauretis, 'The Essence of the Triangle', pp. 25-33; Bono, 'Introduction: Without a Leg to Stand' in Sandra Kemp and Paola Bono (eds), The Lonely Mirror: Italian Perspectives on Feminist Theory, Routledge, London, 1993; and Renate Holub, 'Between the United States and Italy: Critical Reflections on Diotima's Feminist/Feminine Ethics' in Giovanna Miceli Jeffries (ed.), Feminine Feminists: Cultural Practices in Italy, University of Minnesota Press, Minneapolis, 1994, pp. 233-60; Carol LazzaroWeis, From Margins to Mainstream: Feminism and Fictional Modes in Italian Women's Writing, 1958-1990, University of Pennsylvania Press, Philadelphia, 1993, pp. 53-64; and Re, pp. 50-74. For a discussion in English of affidamento in the context of the mother-daughter relationship and the reconstruction of the symbolic order, see Adalgisa Giorgio (ed.), Writing Mothers and Daughters: Renegotiating the Mother in Western European Narratives by Women, New York, Berghahn, 2002, pp. 16-18.

37 Discussed in Giovanna Miceli Jeffries, 'Introduction' in Jeffries, p. xv.

38 Laura Grasso quoted in Lazzaro-Weis, p. 54.

39 Lazzaro-Weis, p. 54.

40 Re, pp. 65-6.

41 Annarosa Buttarelli, 'Fare autorità, disfare potere', in Diotima, Oltre l'uguaglianza: Le radici femminili dell'autorità, Liguori Editore, Naples, 1995, p. 87.

42 Buttarelli, p. 88.

43 See my article, 'Feminist Intellectuals as Public Figures in Contemporary Italy', Australian Feminist Studies, vol. 19, no. 44, 2004, pp. 201-12, and chapter 2 in my book, Elusive Subjects: Biography as Gendered Metafiction, Troubador, Leicester, 2005, pp. 41-81.

44 Dominijanni, 'Lost in Transition', p. 207.

45 Julia Kristeva, 'Is There a Feminine Genius?', Critical Inquiry, vol. 30, 2004, p. 497.

46 The Milan Women's Bookshop Collective, 'More Women than Men', p. 14.

47 The Milan Women's Bookshop Collective, 'More Women than Men', p. 15.

48 This summary of canonical literature on authority is based on Kathleen Jones's book, Compassionate Authority:

Democracy and the Representation of Women, Routledge, London, 1993, pp. 236-40.

49 Jones, p. ix.

50 Dominijanni, cited in Bono, 'Women's Biographies and Autobiographies', p. 11. 